\title{
EFEKTIVITAS EKSTRAK Gracilaria sp. DALAM MENGHAMBAT PERTUMBUHAN MIKROBA IKAN LAYANG DAN TUNA PADA PENYIMPANAN SUHU RUANG
}

\author{
Marni Kaimudin ${ }^{\star}$, Trijunianto Moniharapon ${ }^{2}$, Meigy Nelce Mailoa $^{2}$, Fredy Pattipeilohy ${ }^{2}$ \\ ${ }^{1}$ Balai Riset dan Standardisasi Industri Ambon, Ambon \\ Jalan Kebun Cengkeh (Batu Merah Atas) 97128 Ambon \\ ${ }^{2}$ Fakultas Perikanan dan Ilmu Kelatan, Universitas Pattimura Ambon \\ Jalan Mr.Chr. Soplanit Poka-Ambon \\ Diterima: 23 September 2020/Disetujui: 23 Desember 2020 \\ *Korespondensi: marnikaimudin72@gmail.com
}

Cara sitasi: Kaimudin M, Moniharapon T, Mailoa MN, Pattipeilohy F. 2020. Efektivitas ekstrak Gracilaria sp. dalam menghambat pertumbuhan mikroba ikan layang dan tuna pada penyimpanan suhu ruang. Jurnal Pengolahan Hasil Perikanan Indonesia. 23(3): 523-531.

\begin{abstract}
Abstrak
Ikan sebagai bahan makanan yang mengandung berbagai macam senyawa bioaktif dan cepat busuk pada penyimpanan suhu ruang yang ditandai dengan adanya pertumbuhan mikroba yang disebut TPC. Upaya eksternal untuk memperpanjang umur simpan, dilakukan penelitian bertujuan untuk mengetahui efektivitas ekstrak Gracilaria sp. terhadap total mikroba ikan layang dan tuna pada penyimpanan suhu ruang selama 8, 12, 24, 36, 48 dan 72 jam. Metode penelitian yaitu deskriptif kualitatif menggunakan ekstrak dan uji aktivitas air berdasarkan kelemban uap parsial dalam bahan (ikan) terhadap tekanan uap murni. Efektivitas ekstrak Gracilaria sp. 3\% terbaik pada penyimpanan ikan di jam ke- 36 dengan besaran angka total mikroba yang tumbuh sebesar 2,35 log Cfu/g pada ikan layang dan sebesar 2,35 log Cfu/g pada ikan tuna. Keefektivan ekstrak Gracilaria sp.3\% mempunyai potensi untuk menghambat pertumbuhan total bakteri ikan. Simpangan baku ikan layang segar sebesar 0,39 dan dengan ekstrak sebesar 0,52. Simpangan baku ikan tuna segar sebesar 0,59 dan dengan ekstrak sebesar 0,56. Angka cemaran mikroba yang ditemukan pada ikan layang dan tuna belum melampaui standar mutu mikrobiologi ikan segar yaitu $5 \times 10^{5} \mathrm{CFU} / \mathrm{g}(5,70$ $\log \mathrm{Cfu} / \mathrm{g})$.
\end{abstract}

Kata kunci: Gracilaria sp.,ekstrak, ikan, suhu ruang, total mikroba.

\section{Effectiveness of Gracilaria sp.Extract As An Antimicrobs of Total Microbs FlyingFish and Tuna in Ambient Temperatur}

\begin{abstract}
Fish as a food ingredient contains various bioactive compounds and decays quickly at ambient temperature which is indicated by the presence of microbial growth called TPC. External efforts to extend shelf life, conducted research aimed to determine the effectiveness of Gracilaria sp .. extract against the total microbes of flying fish and tuna at ambient temperature at 8, 12, 24, 36, 48 and 72 hours. The research method was descriptive qualitative. using Gracilaria sp. extract with a concentration of $3 \%$. The test parameters include the total plate count (ALT) with the plate system and the water activity test based on the partial vapor humidity in the material (fish) against pure vapor pressure. The effectiveness of Gracilaria sp. The best $3 \%$ in fish storage at the 36th hour with total number of microbes that grew of $2.35 \log$ Cfu /g in flying fish and $2.35 \log \mathrm{Cfu} / \mathrm{g}$ in tuna. The effectiveness of Gracilaria sp. potential to inhibit the total growth of fish bacteria. Storing raw fish for fresh flying fish is 0.39 and with extract is 0.52 . The standard deviation of fresh tuna is 0.59 and with extract is 0.56 . Results the number of microbial contaminants found in flying fish and tuna has not exceeded the microbiological quality standard for fresh fish, namely $5 \times 10^{5} \mathrm{CFU} / \mathrm{g}$ $(5.70 \log \mathrm{Cfu} / \mathrm{g})$.
\end{abstract}

Keyword: Gracilaria sp, extract, fish, ambient temperature, total microbes. 


\section{PENDAHULUAN}

Ikan merupakan salah satu sumber makanan yang banyak dibutuhkan dan dikonsumsi manusia. Ikan memiliki kandungan protein yang tinggi yang berfungsi sebagai zat pembangun, pengatur, pengganti bagian tubuh atau jaringan yang telah rusak. Protein ikan juga memiliki kandungan asam amino esensial yang dibutuhkan oleh tubuh manusia. Ikan tidak memiliki banyak jaringan pengikat, sehingga ikan dengan mudah dapat dicerna oleh tubuh manusia (Puri 2016; Aprianti 2017), namun termasuk komoditas yang sangat mudah busuk (highly perishable). (Harmita dan Radji 2006; Putro et al. 2016).

Ikan layang (Decapterus) merupakan salah satu komponen perikanan pelagis dengan ukuran antara $15 \mathrm{~cm}$ sampai $25 \mathrm{~cm}$ yang penting di Indonesia (Nontji 2007; Mile 2013), sedangkan ikan tuna (Thunnus sp.) merupakan jenis ikan yang bernilai ekonomis tinggi dan banyak dicari di perairan Indonesia. (Supriatna et al. 2014; Mailoa et al. 2019).

Pada tahun 2011 produksi tuna, tongkol dan cakalang dunia sebesar 6,8 juta ton dan meningkat menjadi lebih dari 7 juta ton pada tahun 2012 dengan rata-rata produksi tuna, tongkol dan cakalang periode tahun 2005-2012 sebesar 1.033.211 ton (KKP 2015; Firdaus 2018). Produksi ikan layang sebesar 427.740,98 ton/tahun (Sangaji et al. 2018).

Dengan kelimpahan potensi, perlu dilakukan upaya untuk memperpanjang kesegaran dan umur simpan ikan karena karakteristik ikan segar yang mudah rusak.

Faktor penyebab percepatan proses pembusukan pada ikan utamanya yaitu aktivitas enzim yang terdapat di dalam tubuh ikan itu sendiri, aktivitas mikroorganisme atau proses oksidasi pada lemak tubuh oleh oksigen dari udara (Putro et al. 2016). Faktor intrinsik yang berasal dari ikan itu sendiri dan tidak dapat dikendalikan oleh usaha apapun seperti adanya komponen zat makanan yang diperlukan mikroba (Susianawati 2006, Febriyanti et al. 2015) dan jumlah kandungan air pada bahan pangan yang dapat mempengaruhi daya tahan bahan pangan tersebut terhadap serangan mikroba yang biasa dikenal sebagai aktivitas air $(A w)$ (Adawyah 2011).
Besarnya aktivitas air memberikan gambaran akan kebutuhan bakteri dalam pertumbuhannya. Nilai $A w$ yang diperoleh menunjukkan jumlah air bebas yang terkandung dalam bahan pangan yang dipergunakan mikroba untuk pertumbuhannya (Syarif dan Halid dalam Lindriati dan Maryanto 2016)

Keberadaan bakteri dalam bahan pangan diukur dengan jumlah koloni per gram bahan pangan melalui analisis total plate count TPC (BSN 2006; Febriyanti et al 2015). Metode ini merupakan salah satu metode kuantitatif yang digunakan untuk mengetahui jumlah mikroba pada suatu sampel atau produk menggunakan media padat dengan hasil akhir berupa koloni yang dapat diamati secara visual dan dihitung, dan interpretasi hasil berupa angka dalam koloni per $\mathrm{mL} / \mathrm{g}$. Cara yang digunakan antara lain dengan cara tuang, cara tetes dan cara sebar (Fardiaz 1989; Susanti et al. 2016; Elfariyanti dan Ismayanti 2015). Batas maksimum bakteri untuk ikan segar yaitu $5 \times 10^{5} \mathrm{cfu} / \mathrm{g}$ (SNI 01-2729. 1-2006; Apriani et al. 2017)

Perkembangan penelitian pemanfaatan produk bahan alam seperti metabolit sekunder, baik senyawa murni maupun dalam bentuk ekstrak menunjukkan peluang untuk dikembangkan karena memiliki efek terapis yang signifikan terhadap bakteri, jamur, maupun virus yang bersifat patogen terhadap hewan dan manusia. Efek terapis yang dinampakkan oleh bahan alam akan lebih aman tanpa efek samping (Parthasarathy et al. 2009; Tarman et al. 2012). Kandungan metabolit sekunder dari rumput laut berpotensi sebagai produser metabolit bioaktif yang beragam dengan aktivitas yang sangat luas sebagai antibakteri, antivirus, dan antijamur (Reskika 2011; Sinurat et al. 2019).

Penelitian bahan alam misalnya Gracilaria sp. yang terbukti efektivitasnya sebagai antibakteri Staphylococcus aureus dan Escherichia coli (Melki et al. 2011), Salmonella enterica sv enteritis dan Pseudomonas aeruginosa (Kaimudin dan Amahoru2018)sertaterhadapbakteri Klebsiella aerogenes (Kaimudin dan Amahoru 2019). Kurniawati et al. (2016) memanfaatkan ekstrak Gracilaria sp. yang dapat memberikan 
efek penurunan tingkat kerusakan pada histopatologi otot ikan mas (Cyprinus carpio). Affandi et al. (2017) melakukan kombinasi biofilter Gracilaria sp. dan zeolit dan memiliki pengaruh yang sangat signifikan terhadap penurunan konsentrasi $\mathrm{Pb}$. Keefektifan Gracilaria sp. sebagai antibakteri disebabkan adanya kandungan metabolit sekunder seperti alkaloid, flavonoid, terpenoid/steroid, saponin dan tanin. Berdasarkan hasil penelitian inilah, dilakukan peneltian dengan tujuan untuk menentukan efektivitas ekstrak Gracilaria sp. dalam mempertahankan mutu ikan layang dan tuna pada penyimpanan suhu ruang.

\section{BAHAN DAN METODE Bahan dan Alat}

Bahan utama yang digunakan adalah rumput laut Gracilaria sp. yang berasal dari Jeneponto (Makassar). Ikan layang dan tuna yang diperoleh dari nelayan di daerah Eri. Bahan pembantu yang digunakan adalah dimethyl sulfured oxide (DMSO), buffer pepton water (BPW), plate count agar (PCA) bermerek Merck dan akuades.

Peralatan yang digunakan dalam penelitian ini antara lain plastik mika, toples kaca bertutup, pisau, talenan, irus, baskom, labu lemak datar, erlenmeyer, kapas, kertas saring kasar, neraca, petridish, tabung reaksi dan rak tabung, pengaduk, beker gelas, botol scott, spiritus, hot plate, pengaduk, oven, autoklaf, evaporator, colony counter, inkubator, dan pompa vakum.

\section{Metode Penelitian Pembuatan ekstrak Gracilaria sp.}

Rumput laut Gracilaria sp. dibersihkan, dikeringkan dan dihaluskan lolos 100 mesh. Gracilaria sp yang telah dihaluskan, kemudian diektraksi dengan pelarut etil asetat teknis. Proses maserasi dilakukan dengan perbandingan bahan baku terhadap solvent yaitu $1: 3$ (Gracilaria sp. : etil asetat) selama $3 \times 24$ jam. Filtrat ekstrak evaporasi pada suhu $45-50{ }^{\circ} \mathrm{C}$ dengan tujuan memisahkan pelarut dari ekstrak Gracilaria sp. yang menghasilkan ekstrak kasar (crude ekstrak) Gracilaria sp.

\section{Pembuatan konsentrasi ekstrak Gracilaria sp. 3\%}

Berdasarkan hasil penelitian pendahuluan tahun 2019 oleh Kaimudin et al. dengan konsentrasi ekstrak 1, 2 dan 3\%, diperoleh hasil total mikroba terbaik dengan perlakuan ekstrak 3\%.

Ekstrak Gracilaria sp ditimbang sebanyak masing-masing $3 \mathrm{~g}$ ke dalam 12 beker gelas yang berbeda. Kemudian ditambahkan masing-masing $5 \mathrm{~mL}$ dimethyl sulfured oxide (DMSO) ke tiap beker gelas untuk melarutkan ekstrak. Selanjutnya ditambahkan akuades hingga $100 \mathrm{~mL}$.

\section{Perendaman sampel ikan layang dan tuna}

Ikan dari nelayan di desa Eri, Ambon disimpan dalam stirofoam ukuran $33 \times 24$ x27 cm bersama dengan es agar tubuh ikan dipertahankan sekitar $4{ }^{\circ} \mathrm{C}$. Proses penanganan ikan layang dan tuna ukuran $33 \times 24 \times 27 \mathrm{~cm}$ (pxlxt) bersama dengan es agar suhu tubuh ikan dipertahankan sekitar $4{ }^{\circ} \mathrm{C}$. Proses penanganan ikan layang dan tuna segar dalam wadah stirofoam dilakukan dengan cara pemberian es secara berlapis yaitu pada bagian dasar diberi es setebal $7 \mathrm{~cm}$, kemudian di atas es diletakan ikan dan bagian atas diberi hancuran es. Setelah pemberian es, wadah stirofoam ditutup rapat, kemudian dibawa ke laboratorium Baristand Industri Ambon. Jumlah es yang dibutuhkan untuk menurunkan suhu ikan layang dan tuna segar sebanyak 10 ekor (berat 2,2 kg) dari suhu awal $27{ }^{\circ} \mathrm{C}$ menjadi $4{ }^{\circ} \mathrm{C}$ menggunakan rumus menurut Afrianto dan Liviawaty tahun 1989 yaitu: berat ikan $\mathrm{x}$ perbedaan suhu $\mathrm{x}$ panas spesifik ikan $=2,2 \mathrm{~kg} \mathrm{x}\left(27-4{ }^{\circ} \mathrm{C}\right) \times 0,84 \mathrm{Kkal}=$ $42,50 \mathrm{Kg} . K k a l$. Untuk melelehkan $1 \mathrm{~kg}$ es batu dibutuh 80 Kkal. Jumlah kebutuhan es adalah $42,50 \mathrm{Kg} . \mathrm{Kkal} / 80 \mathrm{Kkal}=0,53 \mathrm{~kg}$ es.

Ikan layang dan tuna dibersihkan dari sisik, insang, isi perut dan dipotong berukuran 10x6x1,5 cm. Ikan ditimbang masing-masing seberat $100 \mathrm{~g}$, direndam ke dalam masingmasing larutan ekstrak Gracilaria sp. 3\% selama 30 menit. Selanjutnya dilakukan penirisan dan penyimpanan dalam kemasan stirofoam bening berukuran $13 \times 10 \times 3 \mathrm{~cm}$ pada suhu ruangan $25-27^{\circ} \mathrm{C}$ selama 8, 12, 24, 36, 48 
dan 72 jam. Sebagai pembanding, digunakan ikan layang dan tuna tanpa perendaman ekstrak dengan waktu simpan $0,8,12,24,36$, 48 dan 72 jam di suhu ruangan $25-27^{\circ} \mathrm{C}$.

\section{Metode Pengujian \\ Uji Total Plate Count (TPC)}

Uji TPC menggunakan metode hitung cawan merujuk pada SNI 01.2332.3-2006 (BSN 2006). Sampel uji sebanyak $25 \mathrm{~g}$ ditimbang ke dalam pengencer pepton $225 \mathrm{~mL}$. Kemudian dipipet $1 \mathrm{~mL}$ ke masing-masing petridish secara duplo dan diencerkan hingga $10^{-3}$. Media PCA dituangkan ke sebanyak 15$20 \mathrm{~mL}$. Setelah membeku, dimasukkan ke dalam inkubator dengan posisi terbalik dan diinkubasi pada suhu $36 \pm 1{ }^{\circ} \mathrm{C}$ selama \pm 48 jam. Kemudian dilakukan pembacaan hasil total mikrobanya.

\section{Uji aktivitas air bahan (Aw)}

Uji aktivitas air bahan $(A w)$ menggunakan persamaan Belitz et.al., (2009); Leviana dan Paramita (2017).

$$
A w=\frac{P}{P O}=\frac{E R H}{100}
$$

\section{Dimana;}

Aw = Aktivitas air

$\mathrm{P}=$ Tekanan parsial dalam bahan

PO = Tekanan jenuh uap murni

$\mathrm{ERH}=$ Ekuilibrium kelembaban relative

\section{HASIL DAN PEMBAHASAN}

Hasil penelitian menunjukkan bahwa total mikroba ikan layang dan tuna (Figure 1) dan dibuktikan dengan hasil simpangan baku (Table 1) terjadi penurunan total mikroba pada ikan layang dan tuna dengan tambahan ekstrak Gracilari sp. 3\%. Total mikroba ikan layang tanpa perlakuan ekstrak ekstrak Gracilaria sp. 3\% sebesar 3,15-3,47 log cfu/g dan dengan perlakuan ekstrak Gracilaria sp. sebesar 2.35-3.31 log cfu/g. Total mikroba yang terjadi pada ikan tuna tanpa perlakuan ekstrak Gracilaria sp. sebesar 2,96-3,67 log cfu/g dan dengan perlakuan ekstrak Gracilaria sp. sebesar 2,31-3,24 log cfu/g.

Penurunan total mikroba ikan layang dan tuna menunjukkan bahwa adanya efektifitas dari ekstrak Gracilaria sp. dengan konsentrasi 3\%. Kemampuan ekstrak Gracilaria sp. dalam penghambatan total bakteri ikan layang dan tuna dikarenakan metabolit sekunder yang terkandung dalam ekstrak yang mampu menembus dinding sitoplasma ikan untuk menghambat aktivitas mikroba dalam daging ikan terhadap lamanya penyimpanan.

Hasil yang diperoleh dibuktikan dengan perolehan simpangan baku (Tabel 1) yang menunjukkan bahwa total mikroba yang diperoleh dipengaruhi oleh suhu dan waktu simpan. Simpangan baku ikan layang segar sebesar 0,39 dan dengan ekstrak sebesar 0,52. Simpangan baku ikan tuna segar sebesar 0,59 dan dengan ekstrak sebesar 0,56.

Sejalan dengan Mitchell (2013) dalam penelitiannya melaporkan bahwa temperatur dan lama waktu penyimpanan dapat memengaruhi peningkatan jumlah bakteri $E$. coli pada ikan layang. Angka cemaran mikroba yang ditemukan pada ikan layang dan tuna

Table 1 Standard deviation of flying fish and tuna

\begin{tabular}{lcccr}
\hline $\begin{array}{c}\text { Storage time } \\
\text { (hour) }\end{array}$ & $\begin{array}{c}\text { Fresh flying fish } \\
(\log \text { cfu/g) }\end{array}$ & $\begin{array}{c}\text { Flying fish with } \\
\text { Gracilaria extract } \\
(\log \text { cfu/g) }\end{array}$ & $\begin{array}{c}\text { Fresh tuna fish } \\
(\log \text { cfu/g) }\end{array}$ & $\begin{array}{c}\text { Tuna fish with } \\
\text { Gracilaria extract } \\
(\log \text { cfu/g) }\end{array}$ \\
\hline 6 & 3.170188000 & 2.986098000 & 2.964586000 & 2.348738000 \\
12 & 3.230288000 & 2.901720000 & 3.229828000 & 2.476730000 \\
24 & 3.153767000 & 2.756375000 & 3.441141000 & 2.708634000 \\
36 & 3.077484000 & 2.522488000 & 3.962886000 & 2.508169000 \\
48 & 3.405304400 & 3.046304000 & 3.384038000 & 2.512994000 \\
72 & 3.473588800 & 3.313172000 & 3.668616000 & 3.241191000 \\
\hline S2 & 0.154837779 & 0.268336594 & 0.346115101 & 0.319632856 \\
$\mathrm{~s}$ & 0.393494319 & 0.518012156 & 0.588315478 & 0.565360819 \\
\hline
\end{tabular}




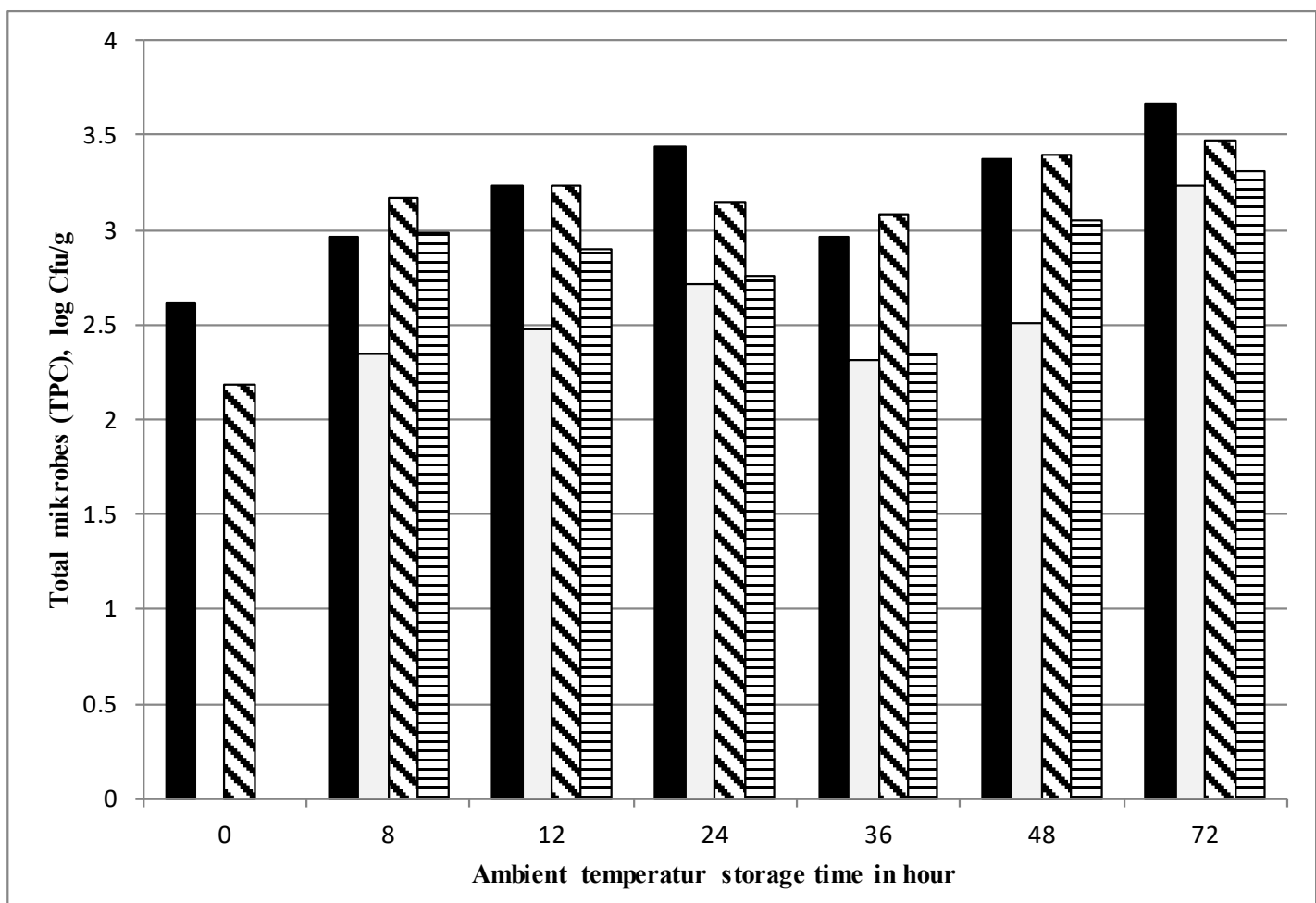

Figure 1 Effectiveness of Gracilaria sp. as an antimicrobes in flying fish and tuna in ambient temperature; $\mathbf{D}$ fresh tuna fish; $\square$ tuna $+3 \%$ extract of Gracilaria sp.; $\mathbb{Q}$ fresh flying fish; 目 flying fish $+3 \%$ extract of Gracilaria sp.

belum melampaui standar mutu mikrobiologi ikan segar yaitu $5 \times 10^{5} \mathrm{CFU} / \mathrm{g}(5,70 \log \mathrm{Cfu} / \mathrm{g})$ (BSN 2006).

Hasil yang berbeda disebabkan juga oleh struktur dinding sel ikan dan kemampuannya dalam melawan aktivitas antimikroba Gracilaria sp. Kemampuan setiap bakteri dalam melawan aktivitas antibakteri berbedabeda tergantung dari ketebalan dan komposisi dinding selnya. Penurunan kualitas ikan dapat dipicu oleh faktor internal misalnya reaksi enzimatis dan faktor eksternal disebabkan oleh parasit atau bakteri. Penurunan mutu ikan dapat terjadi akibat beberapa mekanisme yakni autolisis, aktivitas bakteriologi dan reaksi oksidasi. Husni dan Putra (2015) menegaskan bahwa kerusakan ikan oleh aktivitas bakteri karena jumlah bakteri meningkat karena terus berkembang sehingga menyebabkan pembusukan yang ditandai dengan timbulnya bau busuk dan tekstur daging tidak kompak lagi. Kurniawan et al. (2012) melaporkan bahwa ikan cepat mengalami proses pembusukan jika dibiarkan pada suhu kamar karena komponen air yang besar pada daging ikan sehingga merupakan tempat yang baik bagi perkembangan mikroba pembusuk.

Kaimudin dan Amahoru dalam peneltian tahun 2018 melaporkan bahwa kandungan metabolit sekunder dalam rumput laut Gracilaria sp. antara lain alkaloid, steroid, flavonoid, fenol, saponim, terpenoid dan kuinon. Soamole et al. (2018) menyatakan bahwa metabolit sekunder yang terkanding dalam Gracilaria sp. antara lain alkaloid, terpenoid, steroid, saponin, flavonoid dan tanin. Dengan keberadaan metabolit sekunder dalam ekstrak Gracilaria sp. mampu menembus dinding sitoplasma ikan untuk menghambat aktivitas mikroba dalam daging ikan.

Kandungan metabolit sekunder dalam rumput laut Gracilaria sp. antara lain alkaloid, steroid, flavonoid, fenol, saponim, terpenoid dan kuinon (Kaimudin dan Amahoru 2018; Soamole et al. 2018). Keberadaan metabolit sekunder dalam ekstrak Gracilaria sp. mampu menembus dinding sitoplasma bakteri untuk menghambat aktivitas mikroba dalam daging ikan. Terdapat perbedaan komposisi 
dan struktur dinding sel pada setiap bakteri. Bakteri Gram negatif yang mengandung lipid, lemak atau substansi seperti lemak dalam persentasi lebih tinggi dari pada yang dimiliki oleh bakteri gram positif. Dinding sel bakteri Gram negatif lebih tipis dibanding bakteri Gram positif. Struktur bakteri Gram negatif memiliki membran lapisan luar yang menyelimuti lapisan tipis peptidoglikan. Struktur luar peptidoglikan adalah lapisan ganda yang mengandung fosfolipid, protein dan lipopolisakarida. Lipopolisakarida terletak pada lapisan luar dan merupakan karakteristik bakteri Gram negatif. Untuk sel bakteri Gram positif memiliki dinding sel yang terdiri atas lapisan peptidoglikan yang tebal dimana di dalamnya mengandung senyawa teikoat dan lipoteikoat (Pelczar dan Chan 1986). Oleh karena itu, efektivitas Gracilaria dalam menghambat pertumbuhan bakteri gram negatif dan gram positif dapat berbeda.

Efektivitas ekstrak Gracilaria sp. terbaik terlihat pada pada penyimpanan ikan selama 36 jam dengan besaran angka total mikroba yang tumbuh sebesar 2,31 log cfu/g pada ikan tuna dan sebesar 2,35 log cfu/g pada ikan layang. Pada penyimpanan selama 36 jam, ekstrak Gracilaria sp. 3\% mampu merusak dinding sitoplasma dan mendenaturasi protein sel ikan layang dan tuna secara maksimal sehingga pertumbuhan dan metabolisme bakteri dalam ikan terhambat.

Efektivitas ekstrak Gracilaria sp. terbaik terlihat pada pada penyimpanan ikan selama 36 jam dengan besaran angka total mikroba yang tumbuh sebesar 2,31 log cfu/g pada ikan tuna dan sebesar 2,35 log cfu/g pada ikan layang. Rumput laut memiliki kandungan kimia karagenan dan senyawa fenol,terutama flavanoid. persenyawaan flavanoid sebagai antibakteri menghambat pertumbuhan dan metabolisme bakteri dengan cara merusak membran sitoplasma dan mendenaturasi protein sel (Prajitno 2007). Respons terhadap daya hambat pertumbuhan mikroba yang dihasilkan dipengaruhi oleh kandungan senyawa aktif yang dimiliki. Senyawa aktif Gracilaria sp. mampu menghambat pertumbuhan bakteri Salmonella enterica sv enteritidis sebesar $4,73 \mathrm{~mm}$ dan sebesar 7,91 mm terhadap bakteri Pseudomonas aeruginosa (Kaimudin dan Amahoru 2018). Sabban et al. tahun 2017 juga mengemukakan bahwa senyawa metabolit sekunder seperti senyawa fenol sebagai antibakteri pada konsentrasi rendah dapat merusak membran sitoplasma hingga mengakibatkan kebocoran inti sel. Untuk konsentrasi tinggi, senyawa fenol akan berkoagulasi dengan protein selular. Aktivitas senyawa fenol dalam kondisi konsentrasi tinggi, sangat efektif ketika bakteri dalam tahap pembelahan karena lapisan fosfolipid di sekeliling sel sedang dalam kondisi yang sangat tipis sehingga fenol dapat dengan mudah merusak isi sel.

Faktor intrinsik sebagai salah satu faktor penentu pertumbuhan mikroba dalam bahan pangan yaitu kadar air bahan yang biasa

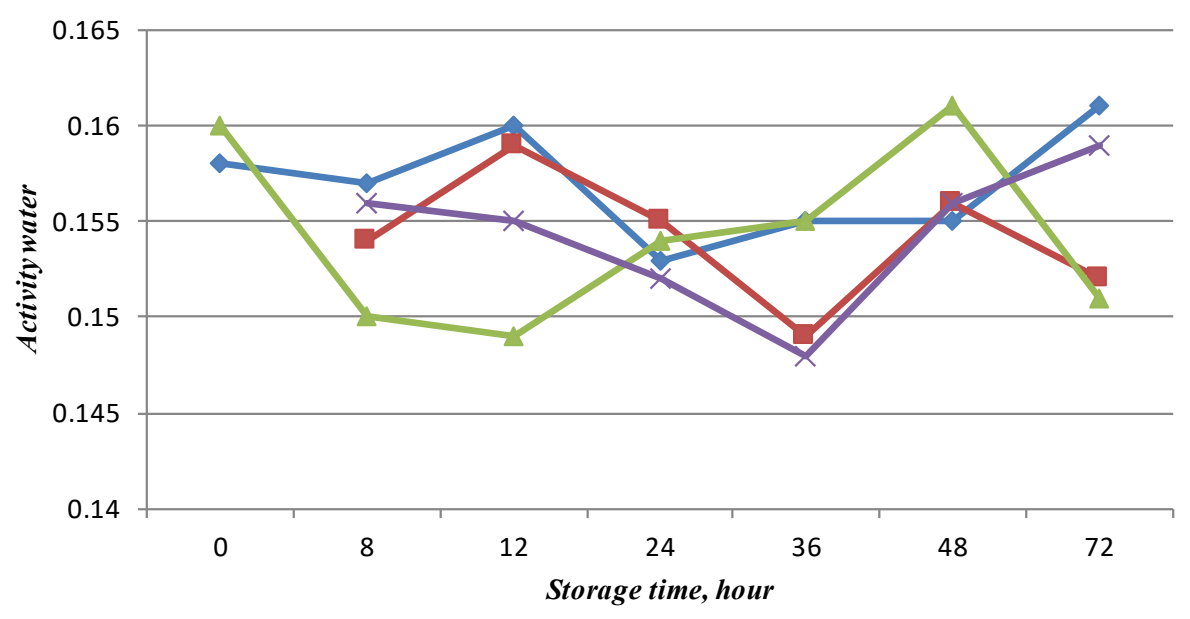

Figure 2 Water activity of flying and tuna fish in ambient temperature; $\longrightarrow$ tuna fish; $-\longrightarrow$ tuna +extract of Gracilaria; $\rightarrow$ flying fish; $\leadsto$ Iflying fish+exctract of Gracilaria. 
dikenal sebagai aktivitas air bahan $(A w)$.

Hasil kadar air bahan yang diperoleh pada ikan layang dan tuna (Figure 2), menunjukkan bahwa aktivitas air ikan layang segar sebesar 0,149-0,161 untuk ikan layang tanpa perlakuan ekstrak dan sebesar 0,1480,159 dengan perlakuan ekstrak. Aktivitas air bahan ikan tuna sebesar 0,153-0,161 tanpa perlakuan ekstrak dan sebesar 0,149-0,159 dengan perlakuan ekstrak.

Perbedaan hasil yang diperoleh menunjukkan perbedaan kelembapan dan tekanan parsial bahan dari ikan layang dan tuna yang berbeda. Jumlah kandungan air pada bahan pangan akan mempengaruhi daya tahan bahan pangan tersebut terhadap serangan mikroba yang dinyatakan sebagai aktivitas air (Aw) (Adawiyah 2011; Hernando 2015; Kumesan 2017).

\section{KESIMPULAN}

Ekstrak Gracilaria sp. 3\% mempunyai potensi untuk menghambat pertumbuhan total mikroba pada ikan yang disimpan pada suhu ruang hingga penyimpanan pada jam ke-36.

\section{UCAPAN TERIMAKASIH}

Terima kasih penulis sampaikan kepada Baristand Industri Ambon dan semua pihak yang telah mendukung dan memberikan bantuan serta kerjasamanya sehingga penelitian ini dapat terlaksana dengan baik.

\section{DAFTAR PUSTAKA}

Adawyah R. 2011. Pengolahan dan Pengawetan Ikan. Jakarta (ID): Bumi Aksaraa.

Affandi AS, Rahardja BS, Suprapto H. 2017. Pengaruh kombinasi biofilter gracilaria $s p$. dan zeolit terhadap logam berat timbal $(\mathrm{Pb})$ pada media air laut. Journal of Aquakultur and Fish Health. 7(2): 10-17.

Apriani R, Ferasyi R, Razali R. 2016. Jumlah cemaran mikroba dan nilai organoleptik ikan tongkol (Euthymus affinis). JIMVET. 01(3):598-603. ISSN:2540-9492.

[BSN] Badan Standardisasi Nasional. 2006. Spesifikasi ikan segar. SNI-2729-2006. Jakarta (ID): Badan Standardisasi Nasional.

[BSN] Badan Standardisasi Nasional. 2006.
Cara Uji Mikrobiologi. Penentuan Angka Lempeng Total (ALT) pada Produk Perikanan. SNI 01.2332.3-2006. Jakarta (ID): Badan Standardisasi Nasional.

[BSN] Badan Standardisasi Nasional. 2009. Batas maksimum cemaran mikroba dalam pangan. SNI 7388-2009. Jakarta (ID): Badan Standardisasi Nasional.

Belitz H.D, Grosch W, Schieberle P, 2009. Food chemistry.

Febriyanti D, Pujiati R.S, Khoiron, 2015. Total plate count dan staphylococcus aureus pada ikan asin manyung (Arius thallasinus) di TPI puger kabupaten Jember. Artikel Ilmiah Hasil Penelitian Mahasiswa.

Firdaus M. 2018. Profil perikanan tuna dan cakalang di Indonesia. Buletin ilmiah "Marina"sosial ekonomi kelautan dan perikanan. 4(1): 23-32.

Harmita, Radji M. 2006. Buku Ajaran Analisis Hayati Edisi 3. Jakarta (ID): Penerbit Buku Kedokteran EGC.

Hernando D, Septionva D, Adihianto K. 2015. Kadar air dan total mikroba pada daging sapi di tempat pemotongan hewan (TPH) Bandar Lampung. Jurnal Ilmiah Peternakan Terpadu. 3(1): 61-67.

Husni A, Putra MP, 2015. Pengendalian Mutu Hasil Perikanan. Yogyakarta (ID): Gadjah Mada University Press.

Kaimudin M, Amahoru SR, 2018. Pemanfaatan ekstrak gracilaria sp. sebagai penghambat bakteri Salmonella enteric sv enteritdis dan Pseudomonas aeroginossa. Majalah BIAM. 14(1):14-21.

Kaimudin M, Amahoru S.R, 2019. Ekstraksi etil asetat gracilaria terhadap penginhibisi senyawa pembentukan histamin. Inovasi litbang hasil perkebunan dalam mengahadapi peluang dan tantangan diera industry 4.0.Prosiding Seminar Nasional Inovasi Teknologi Hasil Perlebuman; 2019 Mei 02-05; Makassar, Indonesia. Hlm 8186. ISSN2686-1186. http:///bbihp.or.id/ ojs.

KaimudinM,ManduapessyK.R.W,Sumarsana, 2020. Potential of seaweed gracilaria sp. as inhibitors of escherichia coli, clostridium perfringens and stapylococcus aureus. IOP Conf. Series: Earth And Environmental Science 517 (2020) 012020. 
[KKP] Kementerian Kelatan dan Perikanan 2015. Rencana Pengelolaan PerIkanan Tuna, Cakalang dan Tongkol. Direktorat Sumber daya Ikan Direktorat Jenderal PerIkanan Tangkap. Jakarta (ID): Kementerian Kelatan dan Perikanan.

Kimball J, Soetarmi S, Sugiri N, 1983. Biologi Jilid 3, edisi ke 5. Jakarta (ID): Erlangga.

Kumesan EC, Pandey EV, Lohoo HJ. 2017. Analisa total bakteri, kadar air dan $\mathrm{pH}$ pada rumput laut (Kappaphycus alvarezii) dengan dua metode pengeringan. Jurnal Media Teknologi Hasil Perikanan. 5(1):3035.

Kurniawan R, Dessy Y, Syahril N. 2012. Analisis Bakteri Pembentuk Histamin pada Ikan Tongkol di Perairan Pasie Nan Tigo Koto Tangah Padang Sumatra Barat. Riau (ID): Universitas Riau.

Kurniawati I, Maftuch, Hariati AM. 2016. Efektifitas ekstrak kasar fenol Gracilaria $s p$. sebagai imunostitmulan terhadap histopatologi otot ikan mas (Cyprinus carpio) yang diinfeksi bakteri Aeromonas hydrophila. Seminar Nasional Perikanan dan Kelautan VI, Fakultas Perikanan dan Ilmu Kelautan, Unibrau Malang; 2016. Akuakultur (A-14): 75-80

Leviana W, Paramita V. 2017. Pengaruh suhu terhadap kadar air dan aktivitas air dalam bahan pada kunyit (Curcuma longa) dengan alat pengering electrical oven. Metana. 13(2):37-44.

Lindriati T, Maryanto. 2016. Aktivitas air, kurva sorpsi isothermis serta perkiraan umur simpan flake ubi kayu dengan variasi penambahan koro pedang. Jurnal Agroteknologi. 10(02):129-136.

Mailoa MN, Lokollo E, Nendissa DM, Harsono P.I, 2019. Karakteristik mikrobiologi dan kimiawi ikan tuna asap. Jurnal Pengolahan Hasil Perikanan Indonesia. 22(1):89-99.

Melki, Wike AEP, Kurniati. 2011. Uji antibakteri ekstrak gracilaria sp. (rumput laut) terhadap bakteri Escherichia coli dan Stapylococcus aureus. Program Studi Ilmu Kelautan FMIPA Universitas.Sriwijaya. 1-6.

Mile L. 2013. Analisis TPD dan total bakteri psikrofilik pada ikan layang (Decapterus macrosoma) selama penyimpanan suhu rendah. Jurnal Ilmiah Perikanan dan Kelautan. 1(2):103-106.

Mitchell LS. 2013. Pengaruh suhu dan waktu penyimpanan terhadap peningkatan kadar histamin pada ikan tongkol. [Skripsi]. Gorontalo (ID): Universitas Negeri Gorontalo.

Nontji A. 2007. Laut nusantara. Edisi revisi. Cetakan kelima. Jakarta (ID): Djambatan.

Parthasarathy S, Azizi JB, Ramanathan S, Ismail S, Mansor SM, Sasidharan S, Said MIM. 2009. Evaluation of antioxidant and antibacterial activities of aqueous, methanolic and alkaloid from mitragyna speciosa (Rubiaceae family) leaves. Molecules 14(10):3964-3974.

Pelczar MJ, Chan ECS. 1986. Fundamentals of Microbiology, vol. I. Hadioetomo R S, Tjitrosomo SS, Angka SL, Imas T. (penerjemah). Jakarta (ID): UI Press Publisher.

Prajitno A. 2007. Uji sensitifitas flavonid rumput laut (Euchema cottnii) sebagai bioaktif alami terhadap bakteri vibrio harveyi. Jurnal Protein. 15(2):66-71.

Putro RFS, Amaliawati N, Sherly. 2016. Pengaruh lama penyimpanan makanan khas Dayak tellu ikan furud (Garra sp.) terhadap angka lempeng total (ALT). Jurnal Teknologi Labratorium. 5(1):32-35.

Reskika A. 2011. Evaluasi potensi rumput laut coklat (Phaeophyceae) dan rumput laut hijau (Chlorophyceae) asal perairan Takalar sebagai antibakteri Vibrio spp. [Skripsi]. Makassar (ID): Universitas Hasanuddin.

Rukmana. 2004. Bertanam Temulawak. Yogyakarta (ID): Kanisius.

Sabban A, Rumahlatu D, Watuguly T. 2017. Potensi ekstrak daun teratai (Nymphaea pubescens L.) dalam menghambat staphylococcus aureus. BIOPENDIX. 3(2):129-141.

Sangaji MB, Tangke U, Namsa D. 2016. Potensi dan tingkat pemanfaatan ikan laying (Decapterus sp) di perairan pulau Ternate. Jurnal ilmiah agribisnis dan perikanan (agrikan UMMU-Ternate). 9(2):1-10.

Sinurat AAP, Renta PP, Herliany NE, Negara BFSP, Purnama D. 2019. Uji Aktivitas antibakteri ekstrak metanol rumput 
laut gracilaria edulis terhadap bakteri Aeromonas hydrophila. Jurnal Enggano. 4(1):105-114.

Soamole HH, Sanger G, Harikedua SD. 2018. Kandungan fitokimia ekstrak etanol rumput laut segar (turbinaria sp., gracilaria sp. dan halimeda macroloba). Jurnal Media Teknologi Hasil Perikanan. 6(3): 94-98.

Supriatna A, Hascaryo B, Wisudo SH, Baskoro M, Nikijuluw VPH. 2014. Model rantai nilai pengembangan perikanan tuna, tongkol dan cakalang di Indonesia. Jurnal
Pengolahan Hasil Perikanan Indonesia. 17(2):144-155.

Susianawati R. 2006. Kajian penerapan GMP dan SSOP pada produk ikan asin kering dalam upaya peningkatan keamanan pangan di kabupaten Kendal. [Skripsi]. Semarang. Universitas Diponegoro.

Tarman K, Prestisia HN, Setyaningsih I, Meydia, Hwang JK, 2012. Kandungan komponen bioaktif dan aktivitas antimikroba ekstrak bintang laut (Culcita schmideliana). Jurnal Pengolahan Hasil Perikanan Indonesia. 15(3):207-215. 